\title{
LATE QUATERNARY ANT FOSSILS FROM PACKRAT MIDDENS (HYMENOPTERA: FORMICIDAE): IMPLICATIONS FOR CLIMATIC CHANGE IN THE CHIHUAHUAN DESERT
}

\author{
By William P. MacKay ${ }^{1}$ And Scott A. Elias ${ }^{2}$
}

\begin{abstract}
Packrat (Neotoma spp.) middens in rock-shelters provide important paleoecological records for the desert regions of North America. Specimens of various arthropod species accumulate in the middens and are cemented into a black, tarry mass by packrat urine.

We collected a variety of ants, including the genera Labidus, Pseudomyrmex (?), Aphaenogaster, Crematogaster, Pheidole, Pogonomyrmex, Solenopsis, Trachymyrmex, Liometopum, and Camponotus in packrat middens from the Chihuahuan Desert. Our data suggest a climatic change in the Chihuahuan Desert from mesic to arid during the past 45,000 years. The coniferous forest, oak-juniper woodland of the early Holocene changed to desertgrassland about 8250 radiocarbon years before present (yr BP), with a corresponding shift in ant species composition. By about $7500 \mathrm{yr}$ BP, the presence of several arid adapted species suggests the establishment of desert environments. Finally after about 2500 yr BP, we see the occurrence of primarily desert adapted ant species in the Chihuahuan Desert, although mesic adapted species continue to occur in moist "islands" within the area. The paleoenvironmental data derived from the ant fossil records agrees closely with previous reconstructions based on other arthropods.
\end{abstract}

\section{RESUMEN}

FOSILES DE HORMIGAS EN NIDOS DE LAS RATAS NEOTOMA: EVIDENCIA POR CAMBIOS DEL CLIMA EN EL DESIERTO CHIHUAHUENSE - Nidos de la rata Neotoma

\footnotetext{
${ }^{1}$ Department of Biological Sciences and Laboratory for Environmental Biology, University of Texas at El Paso, El Paso, TX 79968-0519

2 Institute of Arctic and Alpine Research, University of Colorado, Boulder, CO 80309-0450
}

Manuscript received 22 September 1992 
ofrecen registros paleoecológicos de mucha importancia en las regiones áridas de Norte América. Ejemplares de varias especies de artrópodos se acumulan en los nidos y quedan cementados en una masa oscura formada con la orina de las ratas.

Colectamos una variedad de hormigas de varios géneros en nidos en el desierto chihuahuense en Estados Unidos y México. Nuestros datos sugieren que han habido cambios desde mésico hasta árido en los últimos 45.000 años. Bosques de coníferos, encinos y juníperos cambiaron a pastisales secos durante la primera parte del Holoceno (8.250 años antes del presente). Después hubieron varias especies adaptadas a los desiertos en los años 7.500 antes del presente. Finalmente observamos en forma predominante, la presencia de especies de hormigas adaptadas al desierto en los últimos 2.500 años, aunque quedan otras especies en "islas" mésicas del área. Los datos paleo-ambientales de hormigas están de acuerdo con datos de otros artrópodos.

\section{INTRODUCTION}

Packrat or woodrat (Neotoma spp.) middens are accumulations of objects including edible plants, cactus spines, insect remains, small pebbles and feces. These objects are carried to the den site for a variety of reasons, including food, protection and curiosity. In dry rock-shelters, these remains are cemented into black tarry masses by packrat urine and preserved for thousands of years, providing a rich paleoecological record for the Desert Southwest. This paper discusses fossil ants identified from ancient packrat middens from the Chihuahuan Desert. The midden localities, mostly in mountainous rock shelters and caves, form a northwest-southeast transect across this region (Fig. 1). The samples range in age from $>43,300 \mathrm{yr}$ BP to recent. Plant macrofossil analyses and radiocarbon chronologies have been published for these sites, as summarized by Van Devender (1990).

Elias (1987) made the first substantial report on midden insect assemblages from late Pleistocene and Holocene packrat middens in south-central New Mexico. Other insect fossil studies from packrat middens include sites in southwestern Arizona and northwestern Sonora, México (Hall et al., 1988), and from the Ajo and Puerto Blanco mountains of Arizona (Hall et al., 1989, 1990). Insect fossils (excluding ants) have also been analyzed from sites 


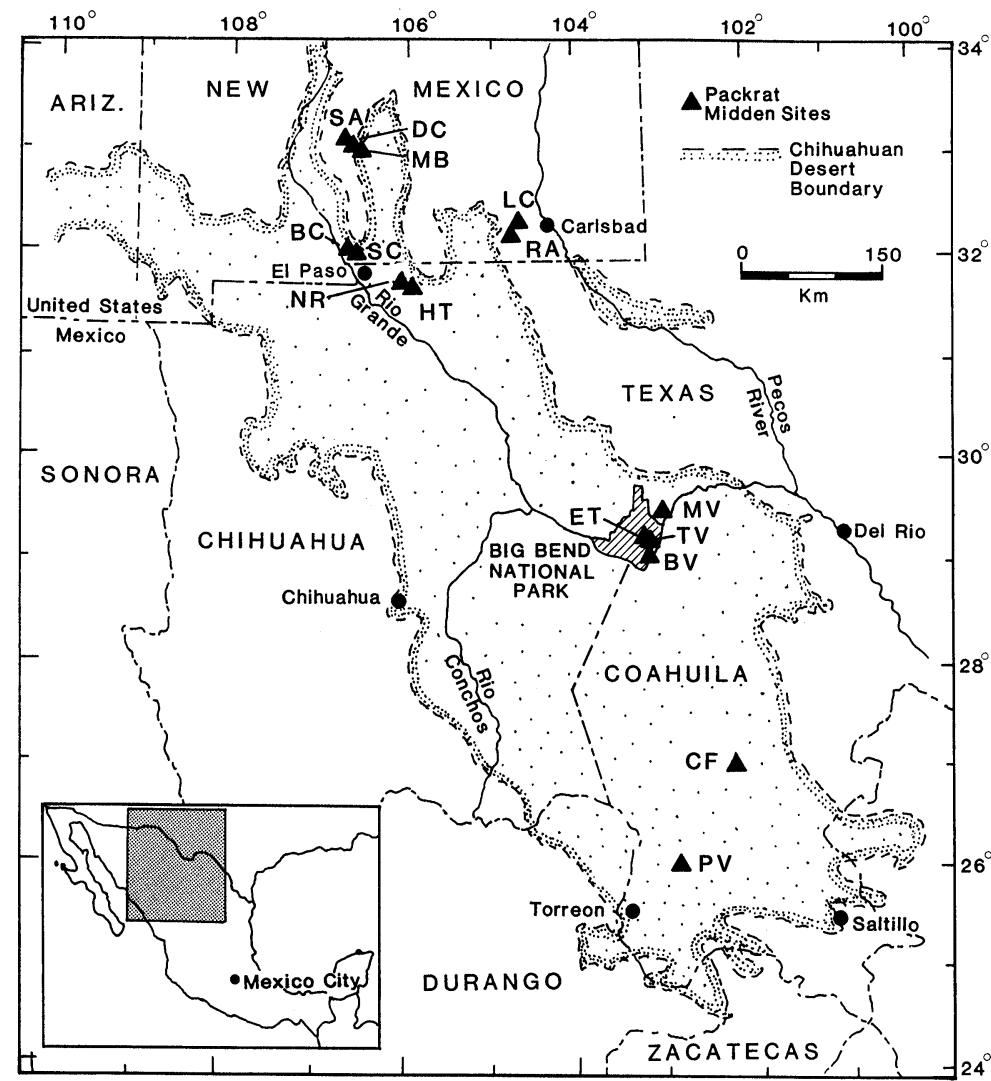

Figure 1. Map of the Chihuahuan Desert region, showing location of packrat midden sites from which ant fossils were identified. BC - Bishop's Cap, New Mexico; BV - Baby Vulture Den, Big Bend National Park, Texas; CF - Cañon de la Fragua, Coahuila, Mexico; DC - Dog Canyon, New Mexico; ET - Ernst Tinaja, Big Bend National Park, Texas; HT - Hueco Tanks State Park, Texas; LC - Last Chance Canyon, New Mexico; MB - Marble Canyon, New Mexico; MV - Maravillas Canyon Cave, Black Gap Wildlife Management Area, Texas; NR - Navar Ranch, Texas; PV - Puerto de Ventanillas, Coahuila, Mexico; RA - Rocky Arroyo, New Mexico; SA - San Andrés Mountains, New Mexico; SC - Shelter Cave, New Mexico; TV - Tunnel View site, Big Bend National Park, Texas. 
reported in this paper (Elias and Van Devender, 1990, 1992; Elias et al., 1992). The taphonomy of insect fossils found in ancient packrat middens has been discussed by Elias (1990).

We are unsure how the ants arrived at the middens. They appear to have been foragers and females ("queens") searching for a nesting site, as only a few individuals of a variety of species were found in any one midden. Some of the specimens could have been blown there. Most of the ants are probably too small to have been carried there by the woodrats. Middens are mesic habitats, with microhabitats more like mesic woodlands than arid deserts (Loring et al. 1987). Presumably ants would nest in such habitats, although nests have not been found in numerous excavated modern middens (Loring et al., personal observation); large numbers of specimens of a single species are likewise not found in middens.

\section{METHODS}

Arthropod exoskeletal remains were sampled from 191 midden assemblages from 27 sites. Of these, 38 assemblages from 15 sites yielded ant fossils. For each assemblage, arthropod remains were sorted from wet-sieved midden matrix samples under a low-power stereo binocular microscope. Ant fossils were mounted on points for identification. The identifications were made using modern specimens for comparison. Most specimens were fragmented and many could not be identified to species. Voucher specimens are curated in the Laboratory for Environmental Biology, University of Texas, El Paso.

\section{RESULTS}

Nineteen species of ants were identified from the midden samples. The ant fossils were recovered from assemblages ranging in age from $>40,000 \mathrm{yr}$ BP to recent (Fig. 2). Six species were found in assemblages ranging in age from $>40,000$ to $10,000 \mathrm{yr}$ BP (Pheidole subdentata, Camponotus mina, C. festinatus, Aphaenogaster nr. texana, Liometopum luctuosum, and Pogonomyrmex barbatus), five species were found in early to midHolocene age samples (Aphaenogaster huachucana, A. albisetosa, Pogonomyrmex apache, $P$. desertorum, and $P$. texanus), and three species were found only in samples younger than $1000 \mathrm{yr} B P$ 


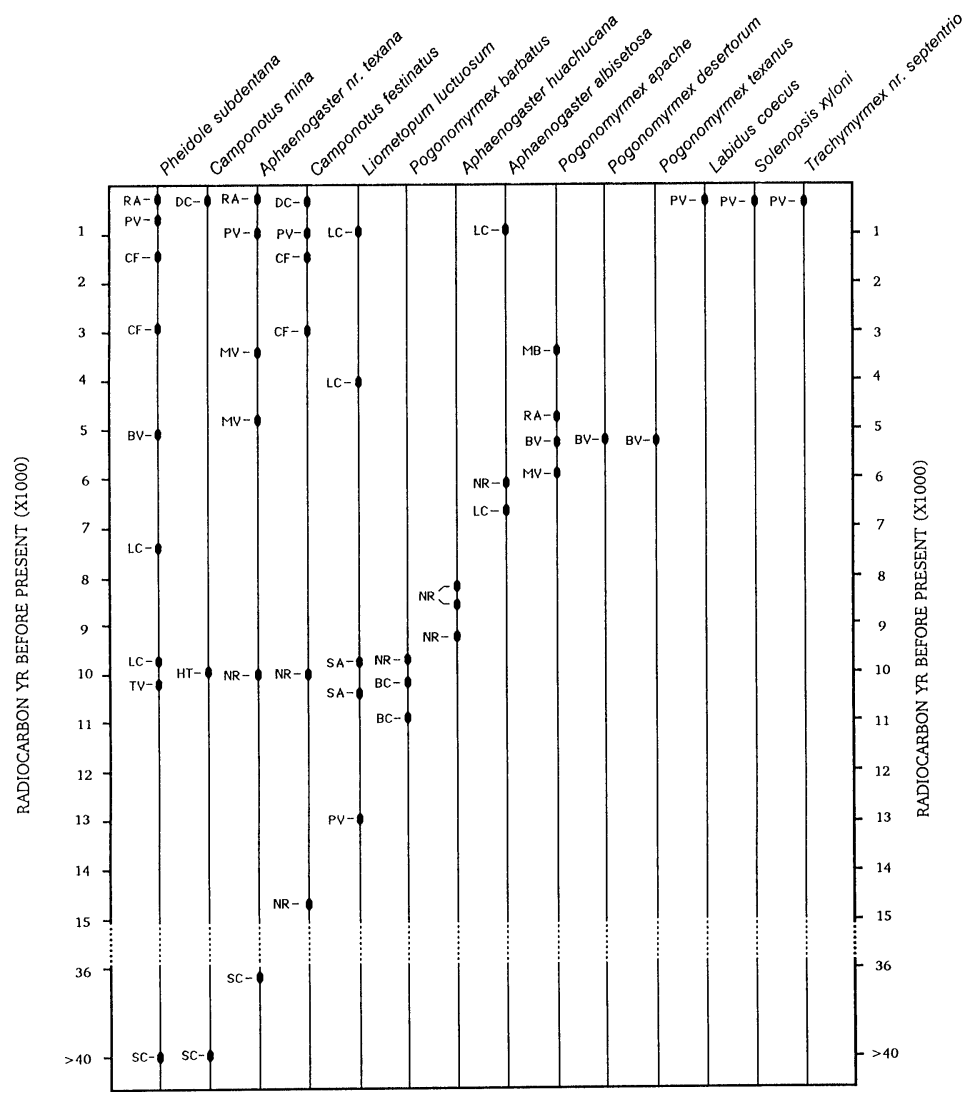

Figure 2. Chronology of fossil ant specimens identified from Chihuahuan Desert packrat middens. For key to site abbreviations, refer to caption of figure 1.

(Labidus coecus, Solenopsis xyloni, and Trachymyrmex nr. septentrionalis).

We found a single species of Ecitoninae: Labidus coecus. This is a tropical species which presently has a limited distribution in North America (Arkansas, Louisiana, Oklahoma, Texas, most of tropical and sub-tropical Mexico south to Argentina). The sample was only about $500 \mathrm{yr}$ old (Table 1) and the midden site (in Coahuila) is within the present distribution of this species. It is 


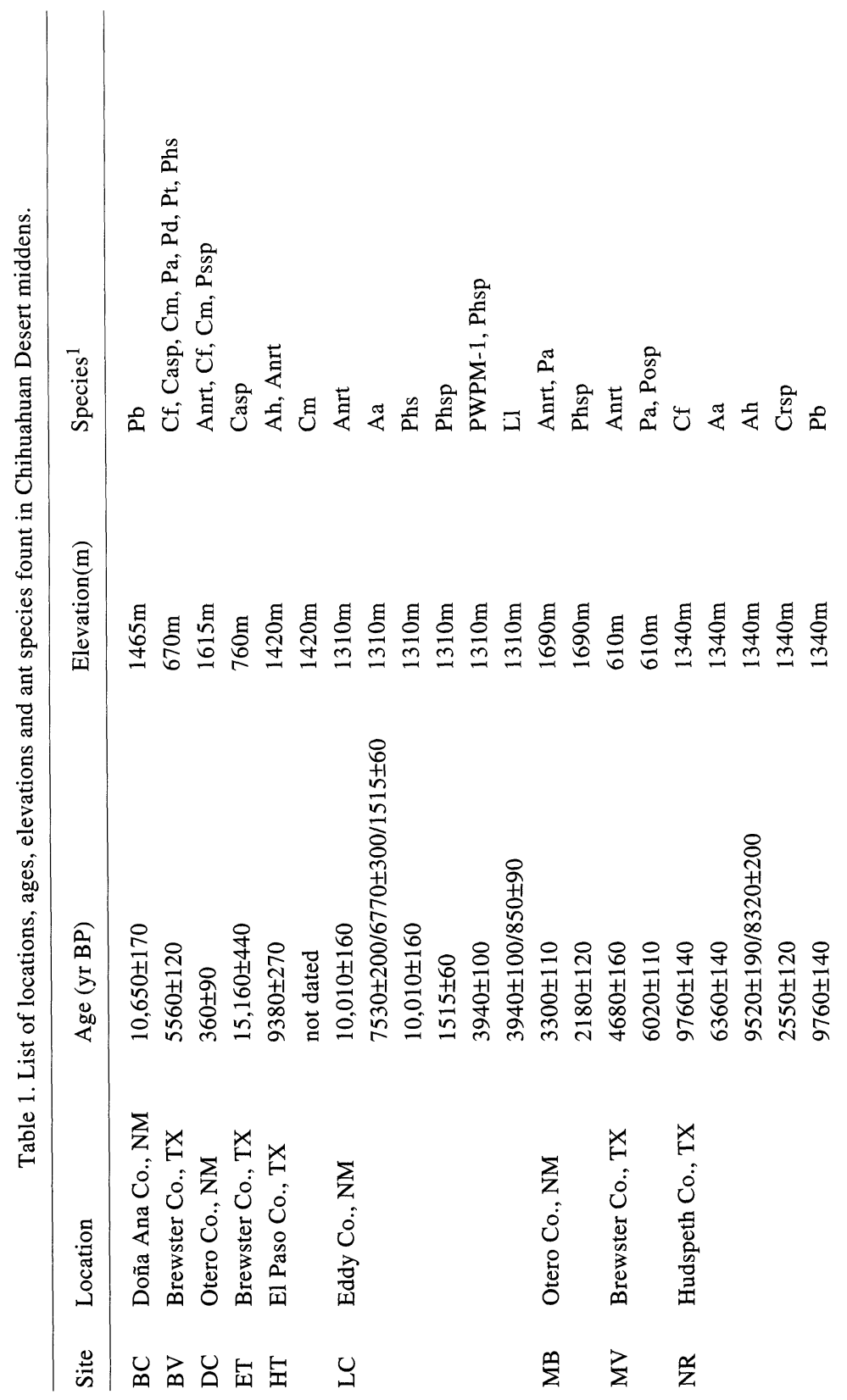




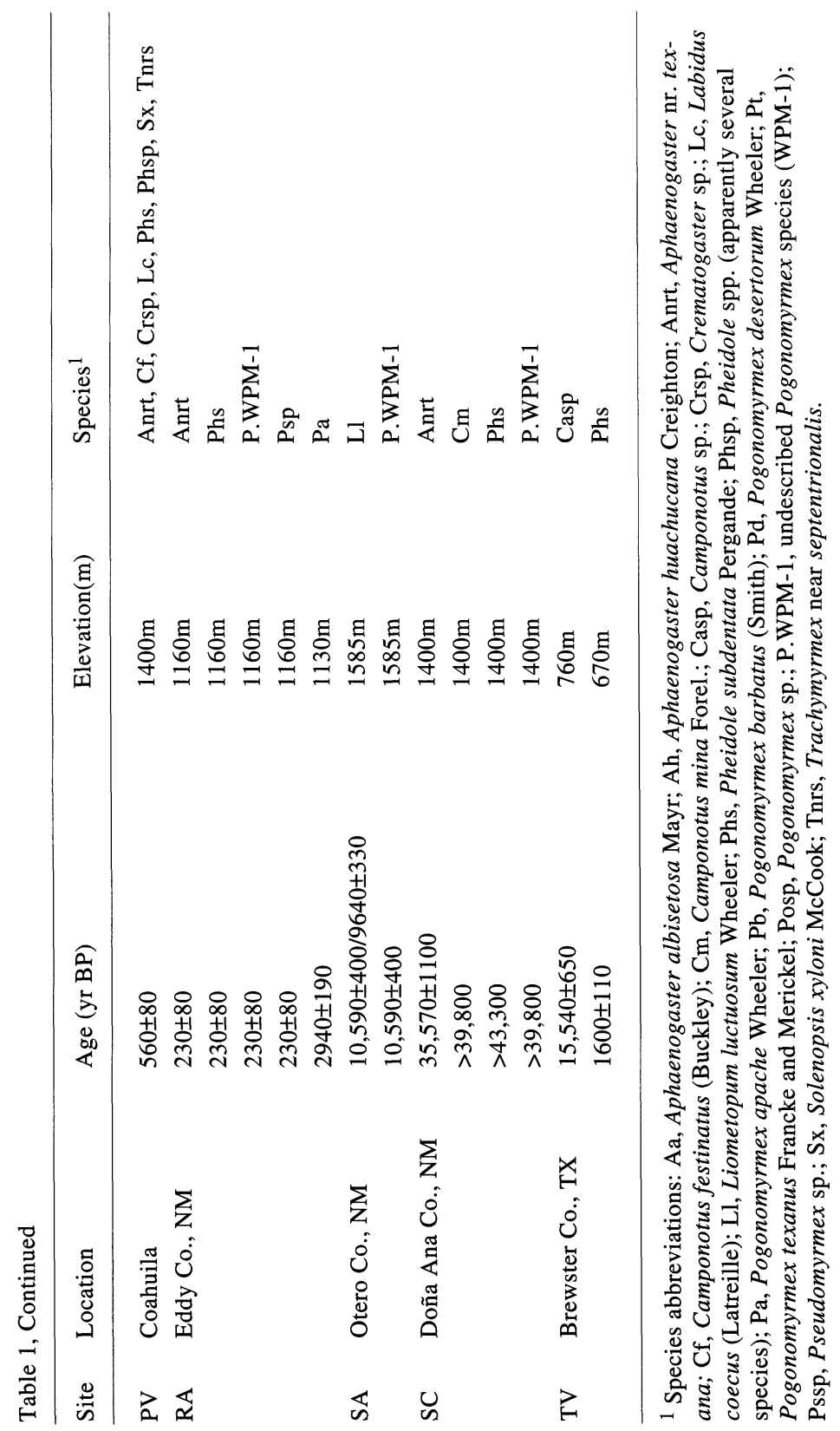


primarily a subterranean predator with reduced nocturnal activity above ground.

One of our specimens appeared to be a male Pseudomyrmex of the subfamily Pseudomyrmecinae, but the specimen was poorly preserved and the identification is questionable.

We identified a variety of ants in the subfamily Myrmicinae, including the genera Aphaenogaster, Crematogaster, Pheidole, Pogonomyrmex, Solenopsis, and Trachymyrmex. Aphaenogaster albisetosa (Fig. 3, A) was found in Eddy Co. NM in deposits which were about 7500 years old. It is common today throughout the southwest USA and northern México in arid and semi-arid regions. It nests in the soil, usually in conjunction with large stones. It is omnivorous, but is also a predator. It is absent from extremely arid environments where $A$. cockerelli dominates. Aphaenogaster nr. texana (Fig. 3, B) is a member of the widely distributed and common texana species complex found throughout the southern USA and northern México. It appears to be most similar to A. punctaticeps MacKay, 1989, but differs in having a more elongate head and less developed propodeal spines. This species was widely distributed in the Chihuahuan Desert during the late Quaternary; it was found in midden samples as old as 35,000 yr BP from Eddy, Otero and Doña Ana Counties in New Mexico, and El Paso and Brewster Counties in Texas. This species was found in recent assemblages from Otero Co. New Mexico, and may still occur in the area. Species of this complex are occasionally found in arid regions, but are most common in mesic habitats including riparian environments and forests. Aphaenogaster huachucana (Fig. 3, C), another member of this species complex, is uncommon and is found today only in Colorado and southern Arizona. In the late Quaternary it was widely distributed in the Chihuahuan Desert, being found as far east as El Paso and Hudspeth Co. Texas about 10,000 years ago (Table 1).

We found identifiable fossil fragments of Crematogaster from two sites (BV and NR in Table 1). This is a common genus, found in a variety of different habitats. Pheidole subdentata (Fig. 3, D \& E) was one of the common species, found in middens from six sites (BV, LC, PV, RA, SC, and TV in Table 1) occurring in the area from 230 to 43,000 years ago. This polymorphic species is not common in the United States (Arizona), but is very common in México, from the state of Chihuahua south to the interior. It is 


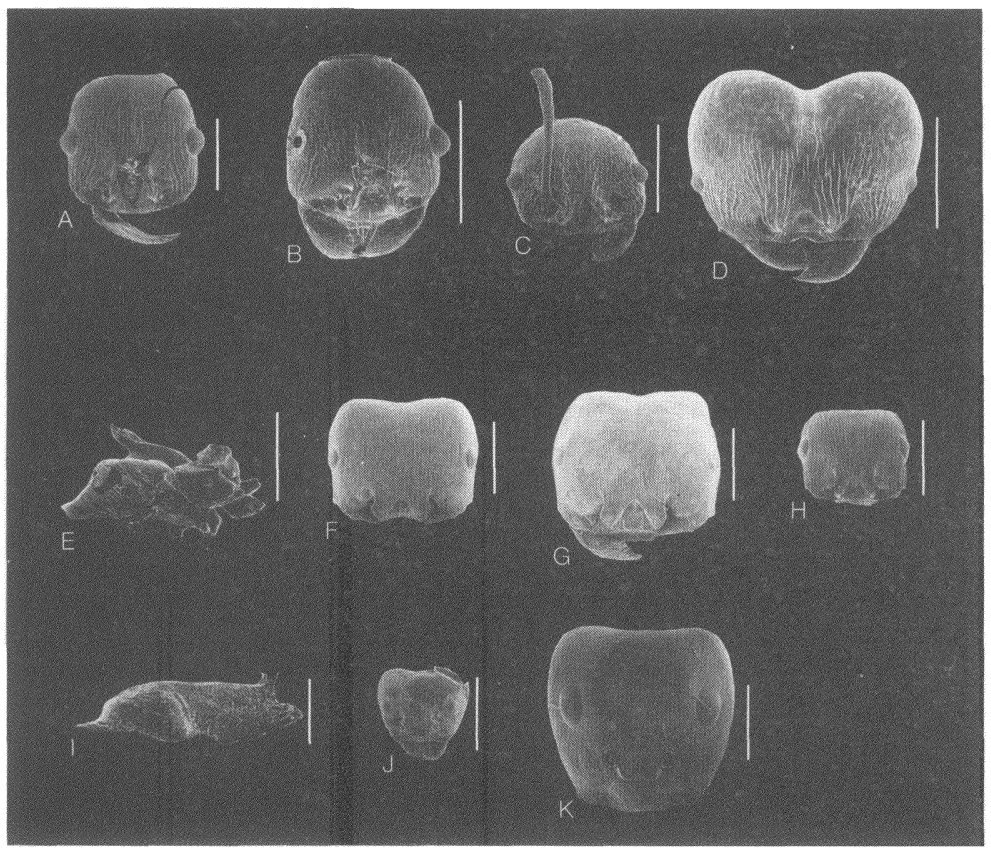

Figure 3. Scanning electron micrographs of fossil ant specimens from Chihuahuan Desert packrat middens. Scale bar equals $1 \mathrm{~mm}$. A, head capsule of Aphaenogaster albisetosa; B, head capsule of Aphaenogaster nr. texana; C, head capsule of Aphaenogaster huachucana; D, head capsule of Pheidole subdentata; E, thorax of P. subdentata; F, head capsule of Pogonomyrmex apache; G, head capsule of Pogonomyrmex barbatus; H, head capsule of Pogonomyrmex species WPM1; I, thorax of $P$. species WPM-1; J, head capsule of Liometopum luctuosum; K, head capsule of Camponotus festinatus.

most common in grasslands and sparse forests, nesting under rocks. We found several other Pheidole species, but these were impossible to identify as they were represented by fragments of workers.

The genus Pogonomyrmex was especially common in our samples. It is one of the most common ant genera throughout the southwestern USA and most of Mexico today. We found $P$. apache (Fig. 3, F) in middens from throughout its present day range, in assemblages spanning the last $6000 \mathrm{yr}$. It is found today from Nevada east to Kansas and south into Chihuahua, and we report it 
here from Coahuila. Pogonomyrmex texanus is closely related to $P$. apache and is presently known only from western Texas and southern New Mexico. We found fossil specimens of this species in middens from Brewster Co. Texas (BV), in assemblages greater than 5000 years old. Both of these species are found in the Chihuahuan Desert today, where they nest in soil. Nests of these ants are difficult to find; they consist simply of an entrance hole with little or no surrounding soil (unusual in the genus) and colonies appear to be very small, probably on the order of a few hundred individuals (also unusual for the genus). Pogonomyrmex barbatus (Fig. 3, G) was also identified in samples from Doña Ana Co., NM and from Hudspeth Co. TX (Table 1). It occurred in the area for several thousand years. This species is widely distributed today in the southern USA south into most of Mexico. It is rarely found in arid habitats (in only urban and agricultural areas), but is very common in mesic habitats throughout its range. It is replaced by the equally common P. rugosus in arid habitats, a species which we did not find in the fossil assemblages. Pogonomyrmex desertorum is another species of this genus, which we found from one fossil site (BV); it occurred there more than 5000 years ago. It is especially common today in arid habitats in the Chihuahuan Desert. It is a small harvester ant that builds small mounds in the soil. We identified several other pieces of specimens of Pogonomyrmex, one of which may represent an undescribed species (WPM-1) (Fig. 3, H \& I). This species is a member of the barbatus complex and is closely related to $P$. barbatus and $P$. rugosus, but differs in that the cephalic rugae diverge posteriorly and are somewhat more coarse. It is also smaller, but may simply be a minim of another species. This species occurred in Eddy Co. and Otero Co. NM from $230-10,000 \mathrm{yr} \mathrm{BP}$ and is probably still present in the area.

The genus Solenopsis was rare in our samples; we found only the species $S$. xyloni. It is a common, widely distributed species in the southern USA and northern Mexico, and is one of the most common species in the Chihuahuan Desert today, with moderately large colonies nesting in the soil. We identified one worker of this species from a midden in Coahuila (Table 1); it occurred there about 500 years ago. 
We found fossils of an undescribed species of Trachymyrmex nr. septentrionalis in midden assemblages from Coahuila (Table 1). It appears to be conspecific with an undescribed species of the genus which occurs today in Chihuahua. When it is found in deserts, this genus usually occurs in mesic habitat islands (i.e., arroyos, playa fringes, etc.). Ants of this genus nest in the soil and use desert vegetation, especially mesquite (Prosopis spp.) to raise fungus gardens. We did not find specimens of $T$. smithi, which is the most common extant southwestern desert species (Arizona, New Mexico, Texas, Chihuahua).

We found only a single representative of the Subfamily Dolichoderinae in our samples. Liometopum luctuosum (Fig. 3, J) was found in middens from Eddy Co. (RA) and Otero Co. (SA) New Mexico. This species nests in dead logs in pine forests at higher elevations (1200-2400 meters) in North America today. It is surprising that we did not find the more common species, $L$. apiculatum, which nests in the soil and logs throughout the Chihuahuan Desert and surrounding oak forests today.

The subfamily Formicinae was represented in the fossil assemblages only by the genus Camponotus. Camponotus festinatus (Fig. $3, \mathrm{~K})$ is one of the most common desert Camponotus species. It nests in the soil under rocks. Camponotus mina is rarely collected, and nests in trees, especially mesquite. It was apparently more common regionally in the past. Our fossil records of $C$. mina extend the distribution from southern Arizona and northern Sonora to New Mexico and the Big Bend region of Texas (Table 1). We found additional pieces of Camponotus which could not be identified.

Our specimens suggest a much more mesic climate in the past. We collected specimens of many species which are presently found only in mesic habitats. For example, we found Pogonomyrmex barbatus instead of $P$. rugosus, which is a dominant species in arid regions today. Our Pogonomyrmex species belonged to the barbatus species complex, not to the maricopa complex, which is common in this region today. We also found the forest inhabiting Liometopum luctuosum instead of the desert adapted $L$. apiculatum. Many of the species we found in the fossil assemblages are rarely found today, and seem to be remnants of much larger populations in the past. 


\section{Discussion}

The late Quaternary paleobotanical record of the Chihuahuan Desert has been summarized by Van Devender (1990). The vegetation gradients of the Chihuahuan Desert reflect regional precipitation and temperature regimes, with desert-scrub communities in the hot, dry lowlands of the Big Bend of Texas (600-1675 m) and at the southern end of the desert in the Bolsón de Mapimí $(1075-2000 \mathrm{~m})$, gradually replaced by desert-grassland to the north, west, south and southeast. Pine-oak woodland and pine forest occur at higher elevations (montane islands) in the desert, and on the surrounding mountain ranges (Van Devender, 1986). The Bolsón de Mapimí vegetation reaches its northern limit in the Rio Grande lowlands (600-1070 m) from Big Bend National Park to northwest of Presidio, Texas. The desert in the Big Bend region is bounded by grasslands and oak woodlands of the Davis Mountains on the north, and by the Chisos Mountains on the south.

At the northern end of the desert, a pinyon-juniper-oak woodland dominated limestone slopes from 1270-1495 m in elevation during the middle to late Wisconsin interval $(42,000$ to $10,800 \mathrm{yr}$ BP). Early Holocene oak-juniper woodland gave way to desertgrassland after about 8,250 yr BP. After about 4,200 yr BP, desert plant species migrated into the northern Chihuahuan Desert region, forming a relatively modern desert-scrub vegetation on rocky slopes. The fossil arthropod assemblages (mostly Coleoptera) from the northern region exhibit a series of species shifts indicative of substantial environmental change since the middle of the last glaciation (Elias, 1992). In full-glacial (22,000-18,000 yr BP) assemblages, the arthropod record suggests that coniferous woodland was widespread. Ant species adapted to mesic habitats were present in these areas, including Liometopum luctuosum, Pogonomyrmex barbatus, Aphaenogaster nr. texana, A. huachucana, Camponotus mina and Pheidole subdentata. From about 22,000 to 11,000 yr BP, woodland environments persisted, but the insect data suggest that there was considerable open ground, with grasses at least locally important. The transition from the Wisconsin-age temperate fauna to the more xeric fauna of the post glacial interval started at about $12,500 \mathrm{yr} \mathrm{BP}$, with the arrival of the first xericadapted species. By about 7500 yr BP, the appearance of additional xerophilous species indicates the establishment of desert 
environments, including desert grasslands. During this time mesic adapted ant species were replaced by arid adapted species, including Pogonomyrmex spp. and Pheidole spp. After $2500 \mathrm{yr} \mathrm{BP}$, the last of the temperate ant species were replaced by species associated with desert-scrub communities, including such species as Pogonomyrmex desertorum and $P$. apache.

In the Big Bend region, the insect assemblages suggest greater effective moisture during the late Wisconsin interval (ca. 30,000 to $12,000 \mathrm{yr} \mathrm{BP}$ ), with an especially diverse, mesic fauna during the earlier part of this interval. Ant species present at that time included Camponotus spp. By latest Wisconsin times, many grassland species occurred in the Big Bend region that are now confined to cooler, moister regions to the north and to higher elevations. After 12,000 yr BP, most of these temperate grassland species are replaced by either desert species (Pogonomyrmex desertorum, Camponotus festinatus) or by more cosmopolitan taxa that are known today from both desert and grassland (Pogonomyrmex apache, $P$. texanus, Pheidole subdentata). This change suggests a climatic shift from cool, moist conditions of Wisconsin glacial times to hotter, drier conditions of latest Wisconsin and early Holocene time. In Big Bend, the insect species indicative of more severe aridity are first recorded at about $6000 \mathrm{yr} \mathrm{BP}$, with some relatively temperate species persisting until about 2500 yr BP. Mesic species are still found in the area in mesic "islands" (Van Pelt, 1983; MacKay and Anderson, 1991).

In the Bolsón de Mapimí, paleobotanical analyses show that the late Wisconsin vegetation on the limestone slopes was a woodland dominated by junipers (Juniperus sp.) and papershell pinyon (Pinus remota) in association with succulents. The abundance of papershell pinyon declined from 13,120 to $12,380 \mathrm{yr}$ BP as succulents increased. The late glacial insect assemblages, ranging in age from 13,590 to $12,280 \mathrm{yr} \mathrm{BP}$, comprise a mixture of temperate and desert taxa (Elias et al., 1992). However, most of the desertassociated species are phytophages, and their presence in the fossil assemblages is more indicative of certain desert floristic elements than of xeric climate per se. Several of the beetle species identified from late glacial assemblages have tropical to subtropical affinities. There is a temporal hiatus in the midden samples from 12,000 to $9000 \mathrm{yr}$ BP, after which most of the late glacial insect species 
disappear from the records. Beetles associated with desert-scrub communities dominate in the early and middle Holocene assemblages. In the late Holocene, several different insect species are recorded, including both temperate species and desert species. Both the paleobotanical and arthropod records from the Bolsón de Mapimí indicate that this region served as a refugium for desert biota during the late Pleistocene. The southerly latitude of this region appears to have dampened the climatic effects of the Wisconsin glaciation to the extent that desert species could survive there, at least during the late glacial interval but also presumably prior to this. A mosaic of temperate and xeric habitat has been available to the regional biota, even during the last $1000 \mathrm{yr}$, when other regions of the Chihuahuan Desert have experienced extremes of aridity (Elias and Van Devender, 1990, 1992). The only Mexican midden sample that yielded ant fossils (the PV site in Coahuila) was dated to the late Holocene arid interval. It contained several species of ants (Table 1), including desert, grassland, and tropical species, all of which live in Mexico today.

The paleoenvironmental conditions inferred from the fossil ant data agree quite well with paleoenvironmental reconstructions based on other fossil arthropods (mostly beetles). While this degree of harmony is gratifying, it is not unexpected. Most of the ant species found in our samples are detritivores or predators, and are therefore not tied to specific types of vegetation. Detritivores and predators are more common in desert insect communities than in the temperate zone (Crawford, 1988); these are useful adaptations in regions of scarce food resources. Many of the beetle species found in the fossil midden samples (e.g., in the families Carabidae and Tenebrionidae) are detritivores or predators.

\section{ACKNOWLEDGEMENTS}

We would like to thank Dr. T. R. Van Devender, ArizonaSonora Desert Museum, Tucson, for providing the midden samples, radiocarbon chronologies, and paleobotanical information on the study sites. Scanning electron micrographs were taken with the assistance of P. E. Carrara and J. Nishi, U. S. Geological Survey, Denver. Financial support for the Chihuahuan Desert insect fossil project was provided by a grant to Elias and Dr. J. C. Halfpenny, INSTAAR, from the National Science Foundation (BSR-8715810). 
The fossil ant research was supported by the Center for InterAmerican and Border Studies, and by the University Research Institute of the University of Texas at El Paso.

\section{REFERENCES CITED}

CRAWFORD, C. S.

1988. Surface-active arthropods in a desert landscape: influences of microclimate, vegetation, and soil texture on assemblage structure. Pedobiologia 32: 373-385.

Elias, S. A.

1987. Paleoenvironmental significance of Late Quaternary insect fossils from packrat middens in south-central New Mexico. Southwest. Nat. 32: 383-390.

1990. Observations on the taphonomy of late Quaternary insect fossil remains in packrat middens of the Chihuahuan Desert. Palaios 5: 356-363.

1992. Late Quaternary zoogeography of the Chihuahuan Desert insect fauna, based on fossil records from packrat middens. J. Biogeogr. 19: 285-298.

Elias, S. A. And T. R. VAn Devender

1990. Fossil insect evidence for late Quaternary climatic change in the Big Bend region, Chihuahuan Desert, Texas. Quat. Res. 34: 249-261.

1992. Insect fossil evidence of late Quaternary environments in the northern Chihuahuan Desert of Texas and New Mexico: comparisons with the paleobotanical record. Southwest. Nat. 37: 101-116.

Elias, S. A., T. R. Van Devender and R. De Baca

1992. Insect fossil evidence of late glacial and Holocene environments in the Bolson de Mapimi, Chihuahuan Desert, Mexico: comparisons with the paleobotanical record. Submitted to J. Quat. Sci.

Hall, W. E., T. R. VAN Devender AND C. A. Olson

1988. Late Quaternary arthropod remains from Sonoran Desert packrat middens, southwestern Arizona and northwestern Sonora. Quat. Res. 29: 277-293.

Hall, W. E., C. A. Olson and T. R. Van Devender

1989. Late Quaternary and modern arthropods from the Ajo Mountains of southwestern Arizona. Pan-Pac. Entomol. 65: 322-347.

1990. Late Quaternary and modern arthropods from the Puerto Blanco Mountains, Organ Pipe Cactus National Monument, southwestern Arizona. In Betancourt, J. L., T. R. Van Devender and P. S. Martin (eds.), Packrat Middens: the last 40,000 years of biotic change. University of Arizona Press, Tucson, pp. 363-379.

LORING, S. J., G. G. WhitFord, J. C. ZAK AND W. P. MACKAY

1987. The influence of wood rats (Neotoma spp.) on chemical and physical parameters of Chihuahuan and Sonora desert soils. Bull. Ecol. Soc. Amer. 68: 353 .

MACKAY, W. P.

1989. A new Aphaenogaster (Hymenoptera: Formicidae) from southern New Mexico. J. N. Y. Entomol. Soc. 97: 47-49. 
MCKAY, W. P. AND R. S. ANDERSON

1991. New distributional records for the ant genus Ponera (Hymenoptera: Formicidae) in North America. J. N. Y. Entomol. Soc. 99: 696-699.

VAN DEVENDER, T. R.

1986. Climatic cadences and the composition of Chihuahuan Desert communities: the Late Pleistocene packrat midden record. In Diamond, J. and T. J. Case (eds.), Community Ecology. Harper and Row, New York, pp. 285-299.

1990. Late Quaternary vegetation and climate in the Chihuahuan Desert, United States and Mexico. In Betancourt, J. L., T. R. Van Devender and P. S. Martin (eds.), Packrat middens, the last 40,000 years of biotic change. University of Arizona Press, Tucson, pp. 104-133.

Van Pelt, A. F.

1983. Ants of the Chisos Mountains, Texas (Hymenoptera. Formicidae). Southwest. Nat. 28: 137-142. 

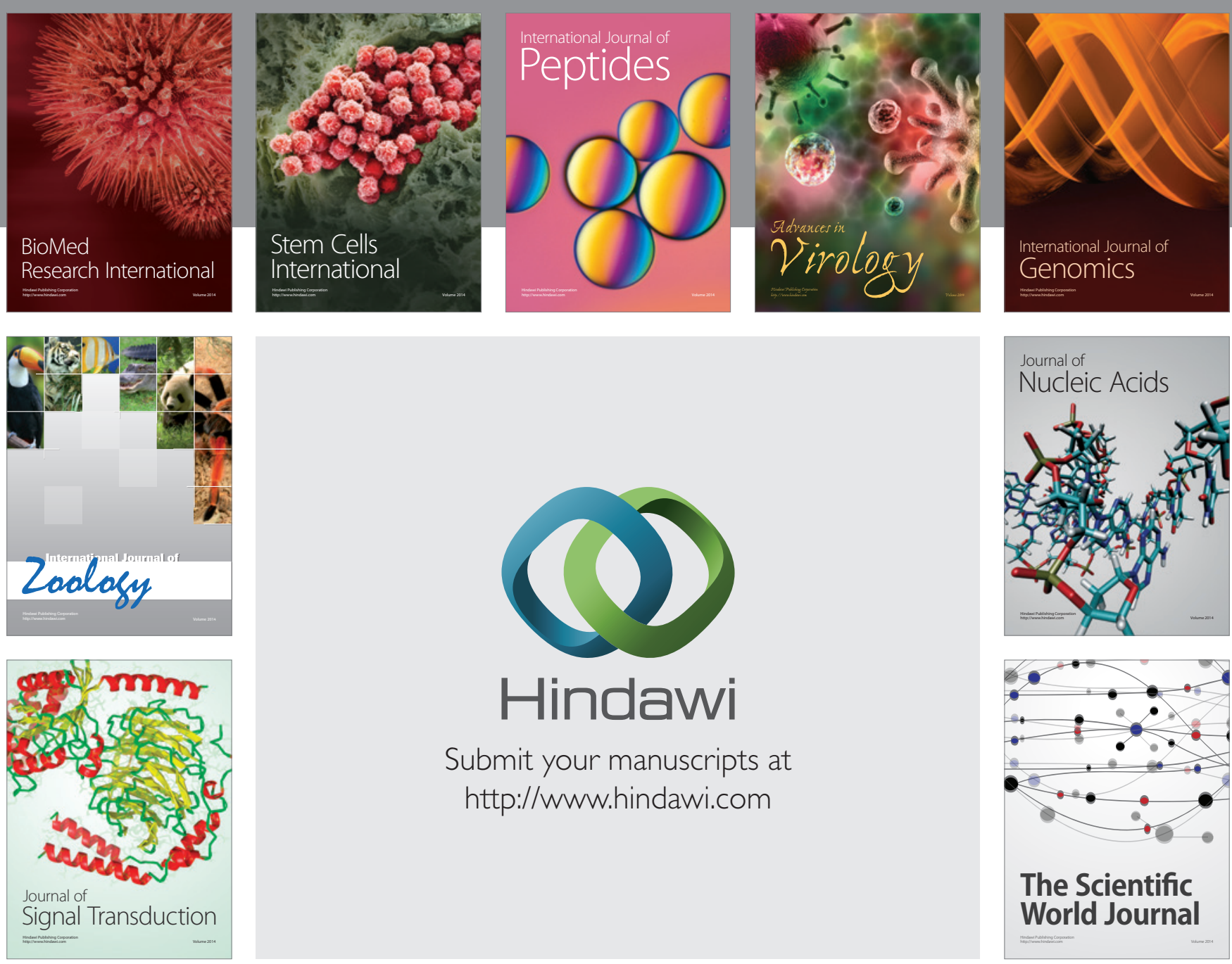

Submit your manuscripts at

http://www.hindawi.com
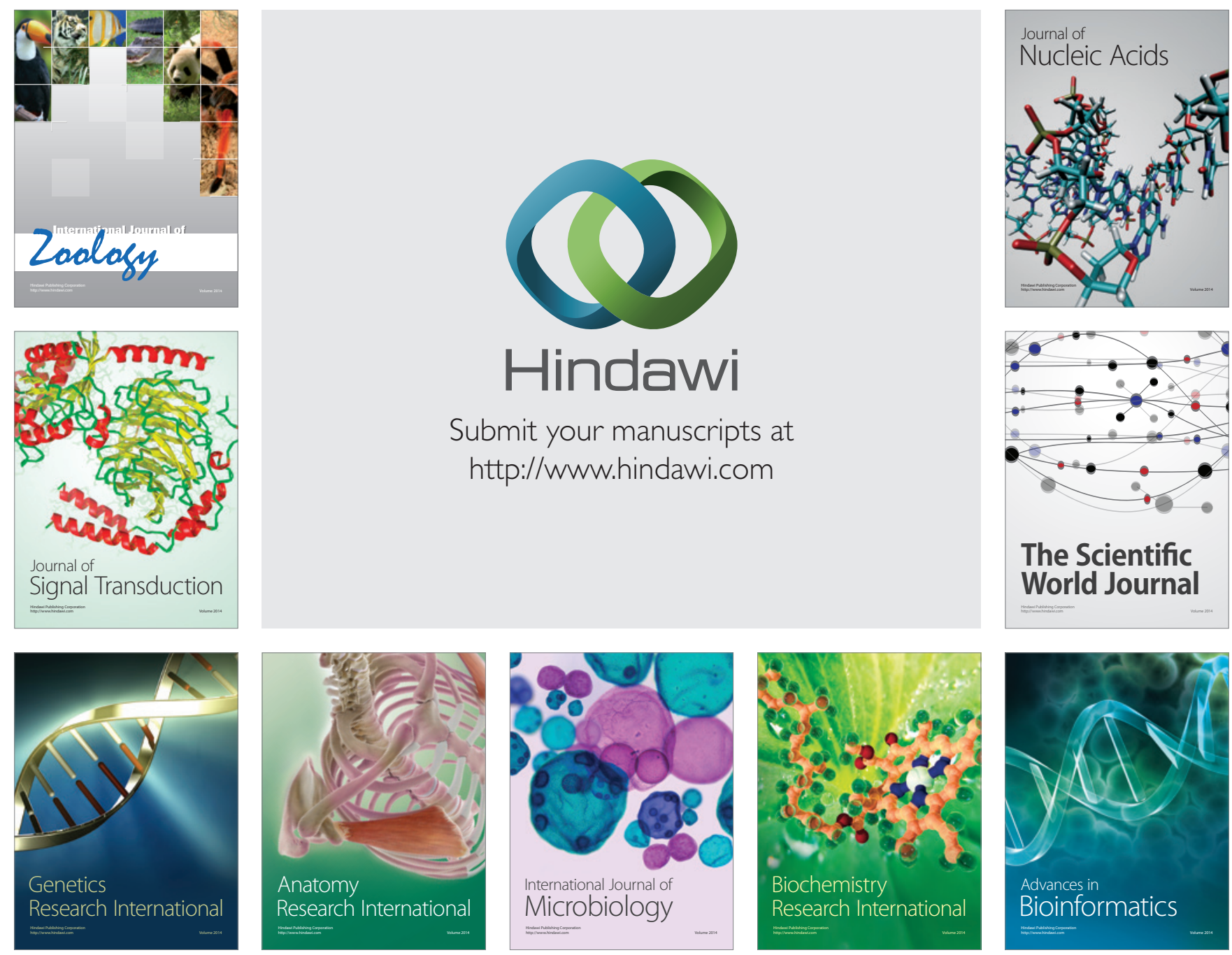

The Scientific World Journal
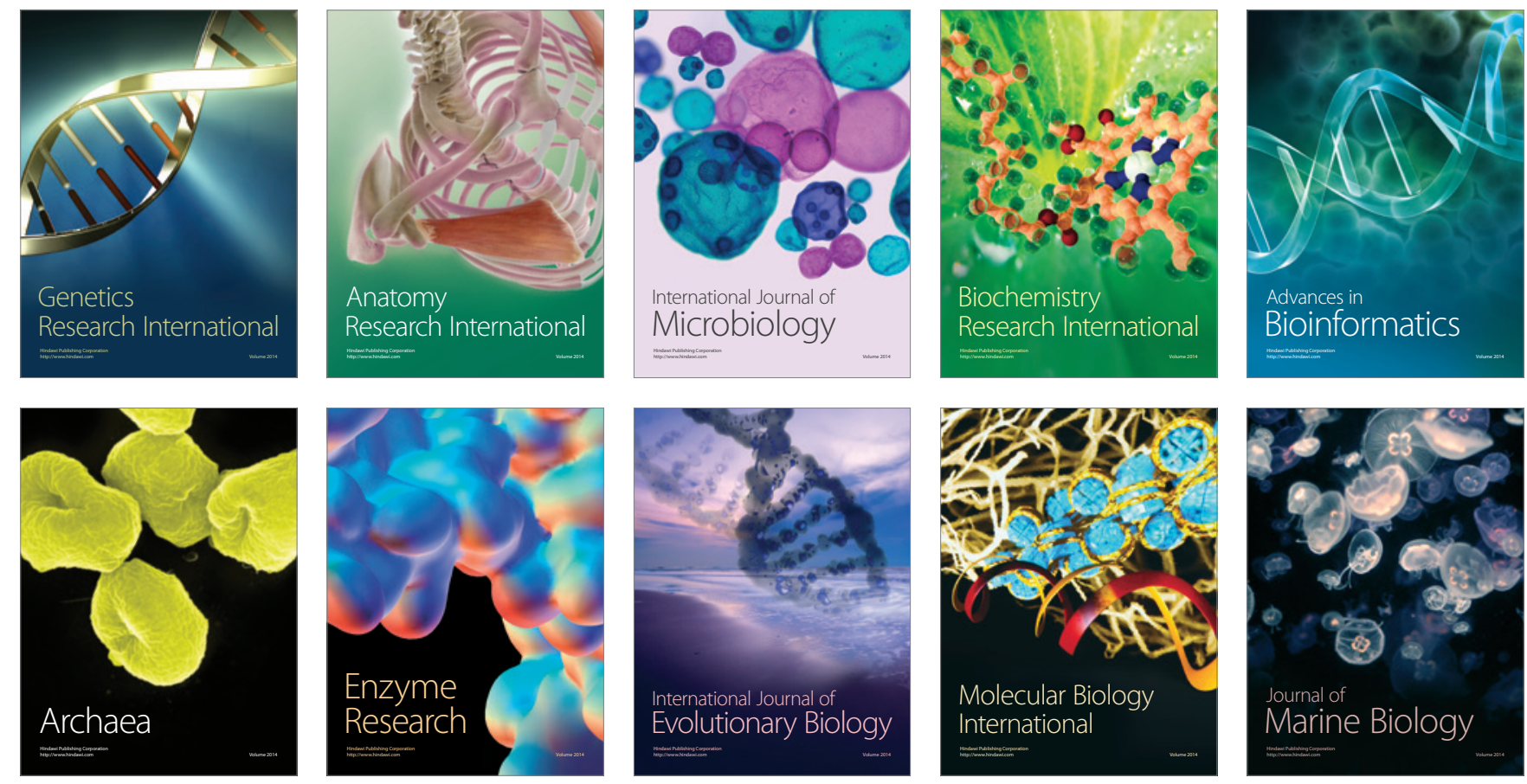